\title{
Planes urbanísticos y planes de vivienda: la extraña pareja
}

\section{Urban plans and housing plans: the strange couple}

\author{
Marcos Vaquer Caballería \\ Universidad Carlos III de Madrid \\ marcos.vaquer@uc3m.es
}

\section{RESUMEN}

Tanto los planes urbanísticos como los de vivienda deberían procurar la efectividad del derecho a disfrutar de una vivienda digna y adecuada, por imperativo constitucional. Sin embargo, la disparidad de las competencias para aprobarlos y de sus plazos de vigencia han contribuido a que se dieran la espalda históricamente, así como a la descoordinación de las técnicas de las que se sirven. En este estudio se analizan estos problemas y se formulan algunas propuestas para superarlos.

\section{PALABRAS CLAVE}

Plan urbanístico, plan de vivienda, derecho a una vivienda, vivienda protegida, vivienda dotacional.

\begin{abstract}
Both urban and housing plans should be devoted to the effectiveness of the right to decent housing, according to the Constitution. Nevertheless, the disparity of their competences, terms of validity and technical measures provoked that they turned away and became uncoordinated. This study analyzes those problems and makes some proposals to overcome them.
\end{abstract}

\section{KEYWORDS}

Urban planning, housing plans, right to decent housing, social housing.

\section{SUMARIO}

1. UN DESENCUENTRO HISTÓRICO. 2. UN DERECHO DESATENDIDO. 3. DOS FAMILIAS DE PLANES. 4. DOS COMPETENCIAS DISPARES. 5. DOS TIPOS DE TÉCNICAS DISPONIBLES. 5.1. RÉGIMEN OBJETIVO DEL SUELO. a) La calificación y la reserva de suelo con aprovechamiento lucrativo para vivienda protegida. b) La calificación y la reserva de suelo dotacional para uso residencial. 5.2. RÉGIMEN ESTATUTARIO DE LA PROPIEDAD. a) La participación de la comunidad en las plusvalías y los patrimonios públicos de suelo. b) El derecho de superficie. 6. TRES PROBLEMAS ACTUALES. BIBLIOGRAFÍA DE REFERENCIA. 


\section{UN DESENCUENTRO HISTÓRICO}

En España, ha existido un largo desencuentro histórico entre potestades urbanísticas y políticas de vivienda ${ }^{1}$.

Durante el primer franquismo, se atribuyó esta divergencia a la separación de ambas competencias entre dos ministerios distintos: el de Gobernación y el de Trabajo, respectivamente, hasta la creación del de Vivienda en 1957, lo que propició el que Gabriel Alomar llamó «cantonalismo ministerial» de la época. Pero además, el desencuentro se manifestó pronto en los instrumentos de planificación: la Ley sobre Régimen del Suelo y Ordenación Urbana establecía en 1956 un sistema holístico de planificación territorial y urbanística que pronto se vería desbordado por la aprobación del gigantesco Plan de Vivienda 1961-1976, que anticipaba la lógica de la planificación socio-económica de los Planes de Desarrollo e inauguraba un modelo de planificación de vivienda que subsiste hoy y es ya uno de los pocos supervivientes de la planificación económica.

Ya en las postrimerías del franquismo encontramos otra clara manifestación del desencuentro a que me refiero: las llamadas ACTUR, actuaciones urbanísticas urgentes ideadas para dar cobertura a actuaciones de política de vivienda o industrial, cuyo Decreto de 1970 las legitimaba «aun cuando... no tengan aprobados planes de ordenación urbana, y si los tuvieran, cualesquiera que sean sus las previsiones y el sistema de actuación establecidos en los mismos». De nuevo, la lógica sectorial se imponía a la transversal de la planificación urbanística al socaire de las urgencias de la demanda de vivienda.

Con la llegada de la democracia y la promulgación de la Constitución española de 1978, cabía pensar que se superaría este divorcio, habida cuenta del título competencial que reunía sin solución de continuidad a «ordenación del territorio, urbanismo y vivienda» el art. 148.1.3. ${ }^{a}$ CE entre los que podían asumir en exclusiva las Comunidades Autónomas, como así hicieron todas ellas. ¿Por fin la reunión armónica de suelo y vivienda como objetos de políticas públicas? En un apartado posterior (vid. infra, 4) veremos que no, puesto que en el Estado autonómico conviven un urbanismo eminentemente municipal con una política de vivienda eminentemente autonómica, y por ello han seguido reproduciéndose los desencuentros.

Así, podemos recordar el ejemplo reciente de la Ley 3/1995, de 6 de abril, de Fomento de la Vivienda en Extremadura, más conocida por la «ley del kilómetro» porque permitía en sus artículos 2 y siguientes reclasificaciones directas de suelo no urbanizable o urbanizable no programado a suelo urbano por un procedimiento abreviado, para promociones de vivienda, con el único límite de que se ubicaran en el primer kilómetro del perímetro periurbano, aunque quedaran segregadas de la trama urbana. De esta forma, se habilitaba de forma ágil suelo barato para las políticas de vivienda, aunque fuera en desafío del modelo territorial del plan urbanístico y de la lógica de la expansión urbana racional. Instrumentos más sutiles y sofisticados, pero que habilitan asimismo grandes actuaciones de competencia autonómica de transformación del suelo para vivienda, todo ello al margen del planeamiento urbanístico general municipal y primando sobre él, los encontramos en los Proyectos de Interés Regional y denominaciones similares que abundan en las leyes autonómicas en la materia².

\section{UN DERECHO DESATENDIDO}

La interacción entre políticas de suelo y de vivienda no sólo es un mandato del sentido común, sino también de la Constitución española. En efecto, el artículo 47 de la Constitución no se limita a proclamar que «todos los españoles tienen derecho a disfrutar de una vivienda digna y adecuada», sino que además manda a todos los poderes públicos promover las condiciones necesarias y establecer las normas pertinentes para hacer efectivo este derecho, e identifica claramente uno de dichos medios para tal fin: «regulando la utilización del suelo de acuerdo con el interés general, para impedir la especulación».

El artículo 47 es, sin duda, uno de los preceptos peor interpretados, menos desarrollados y apenas aplicados de la Constitución.

En primer lugar, porque en España se ha desarrollado históricamente un Derecho de la vivienda, pero no un verdadero derecho a la vivienda, como manda hacer el constituyente. En efecto, ya desde la Ley de

1 Al respecto, pueden verse VILLAR EZCURRA, 1980: 347, ALLI ARANGUREN, 2005: 906, o VAQUER CABALLERÍA, $2011: 126$.

2 Sobre estas actuaciones, que desafían en lo dogmático a la concepción del urbanismo como ordenación holística de los usos del suelo, y en lo organizativo a la autonomía municipal y sus competencias en la materia, existe ya una nutrida literatura. Por todos, vid. MENÉNDEZ REXACH, 2016, y VAQUER CABALLERÍA, 2016. 
Casas Baratas de 1911 existe en España un cuerpo legislativo dedicado a la vivienda supuestamente social y que más bien ha servido de instrumento de fomento económico ${ }^{3}$, pero todavía no hemos configurado un derecho subjetivo pleno de las personas en estado de necesidad a disfrutar de una vivienda digna y adecuada. Sólo la última generación de leyes autonómicas en la materia, como la Ley 3/2015, de 18 de junio, de Vivienda del País Vasco, se adentra por esta vía siguiendo los ejemplos del Derecho comparado de las homelessness acts del Reino Unido y la Loi DALO francesa.

En segundo lugar, porque cuando la Constitución habla de vivienda no se refiere a cualquier casa o forma de residencia, sino sólo a la residencia habitual, aquélla en la que se desarrolla efectivamente la vida individual y familiar. Así que todas las informaciones y estadísticas que tratan de la producción u oferta de «vivienda» e incluyen muy diversos tipos de productos residenciales, como la vivienda turística o la secundaria, se apartan del genuino concepto constitucional de vivienda. Y porque cuando emplea el término «disfrutar», lo hace en su acepción de uso o fruición personal (al igual que ocurre en la locución paralela «disfrutar» de un medio ambiente adecuado del art. 45), no en el sentido patrimonial. De modo que dicho disfrute puede procurarse por cualquier título jurídico que incluya la facultad de uso, como ocurre con el arrendamiento, el usufructo o el derecho de superficie, y sin embargo históricamente se ha acumulado gran parte de la inversión pública en la promoción de vivienda protegida en venta.

En tercer y último lugar, porque la Constitución apela a instrumentalizar la regulación de la utilización del suelo al servicio de la efectividad del derecho a la vivienda. Pero, como hemos visto, las políticas urbanísticas y de vivienda se han dado tradicionalmente la espalda y aun hoy, como veremos a continuación, se valen de instrumentos diversos y no siempre coordinados.

\section{DOS FAMILIAS DE PLANES}

Los planes urbanísticos son instrumentos singulares, dotados de eficacia normativa reglamentaria de carácter especial y espacial (consistente en la ordenación de los usos del suelo mediante su clasificación, zonificación y calificación) así como también ejecutiva (en la programación de obras, la habilitación de expropiaciones, etc). Las competencias administrativas para su iniciativa e instrucción suelen ser municipales, y las de aprobación definitiva suelen estar distribuidas entre los municipios y las comunidades autónomas. Y su eficacia temporal suele ser indefinida, sin perjuicio de preverse su revisión en el largo plazo, una vez superado el horizonte temporal de su diagnóstico y modelo territoriales.

Los planes de vivienda son normas reglamentarias, pero ya no espaciales sino abstractas, que determinan tipologías de vivienda protegida y ayudas públicas. Las competencias para su aprobación son formalmente autonómicas, si bien el Estado ejerce títulos competenciales transversales (como el de las bases y coordinación de la planificación general de la actividad económica, ex art. 149.1.13. ${ }^{\mathrm{a}} \mathrm{CE}$ ) para aprobar sus propios planes y destinar sus propios recursos financieros ${ }^{4}$. $Y$ tienen vigencia temporal, tradicionalmente cuatrienal.

Así las cosas, entre los planes urbanísticos y los de vivienda hay disparidad de contenidos, de competencias y de tempo, lo que sin duda dificulta su debida coordinación.

Un posible puente entre las dos orillas pueden construirlo los planes territoriales o urbanísticos especiales. Es decir, instrumentos que traducen en forma de ordenación espacial y, por tanto, insertan en el sistema de planificación urbanística las determinaciones que así lo requieren de las políticas de vivienda, o de cualesquiera otras con impacto territorial.

Esta es al menos la voluntad de la legislación catalana, por ejemplo. La Ley del Derecho a la Vivienda de 2007 instituye el plan territorial sectorial de vivienda (instrumento que, sin embargo, no ha sido aprobado hasta la fecha) y le atribuye la delimitación de ámbitos de demanda residencial fuerte y acreditada (arts. 12 y 73.1 LDV) y los planes locales de vivienda (o los programas de actuación urbanística municipal equivalentes de la ley urbanística) a los que habilita para delimitar áreas sujetas a derechos de tanteo y retracto (arts.

3 Sobre este sesgo tradicional de las políticas de vivienda como políticas económicas sectoriales, orientadas al fomento de la construcción residencial, puede verse BAÑO LEÓN, 2005: 75, BERMEJO LATRE en LÓPEZ RAMÓN, coord., 2010: 193, o VAQUER CABALLERÍA, 2011: 125.

4 En todo caso, el desarrollo y la ejecución de los planes estatales corresponde a las Comunidades Autónomas, como afirman en la actualidad los arts. 1.3 y 3.1 del Real Decreto 233/2013, de 5 de abril, por el que se regula el Plan Estatal de fomento del alquiler de viviendas, la rehabilitación edificatoria, y la regeneración y renovación urbanas, 2013-2016. 
14 y 15 LDV, a lo que los programas citados le añaden la capacidad de delimitar suelo urbanizable, incluir sistemas generales, distribuir reservas de suelo para vivienda protegida, etc.). A su vez, el Texto Refundido de la Ley Urbanística de 2010 instituye el plan director urbanístico, apto para programar las políticas supramunicipales de suelo y vivienda y delimitar y ordenar urbanísticamente las llamadas áreas residenciales estratégicas (arts. 56 y 157 TRLU). Aunque legalmente calificados como instrumentos de planificación general, la vocación de estos planes es claramente especial o sectorial, para la ejecución de concretas políticas públicas, como las de vivienda.

\section{DOS COMPETENCIAS DISPARES}

El alcance de las competencias municipales en materia urbanística y de vivienda es asimismo dispar. El artículo 25.2.a) de la Ley de Bases del Régimen Local les garantiza a los municipios la participación en todo el ciclo de las potestades urbanísticas. «Urbanismo: planeamiento, gestión, ejecución y disciplina urbanística». Mientras que en materia de vivienda sólo les garantiza la «promoción y gestión de la vivienda de protección pública con criterios de sostenibilidad financiera».

Sobre esta base, el Tribunal Supremo ha declarado que «los Ayuntamientos carecen de capacidad, para ordenar, crear o regular un régimen de promoción pública de viviendas, y que las acciones que puedan intentar por la vía de fomento han de respetar y adecuarse a lo establecido al respecto por el Estado y las Comunidades Autónomas que son las que tienen competencia en la materia». (STS de 25 de mayo de 2004, cas. núm. 66/2002). Esto es, que los Ayuntamientos califican suelo pero no vivienda. Deben atenerse a los tipos de vivienda protegida establecidos por el Estado y/o la Comunidad Autónoma, porque carecen de competencia tanto legislativa como ejecutiva en la materia. Sólo disponen de capacidad promotora y gestora de su propio patrimonio de suelo y vivienda, que pueden programar mediante la aprobación de planes municipales de vivienda 5 . Pero tales planes carecen, pues, de la eficacia normativa ad extra que tienen los planes autonómicos de vivienda.

Ahora bien, ni este marco legal básico (que sólo garantiza un mínimo competencial a los municipios) ni esta jurisprudencia (que aplica el Derecho vigente) impiden que una Comunidad Autónoma, en el ejercicio de su competencia exclusiva en materia de vivienda, les atribuyera cierta capacidad de innovación normativa a todos o algunos de los municipios, para establecer tipos adicionales de vivienda protegida o para adaptar a su realidad local las características de los tipos establecidos por las leyes o los planes de vivienda, por ejemplo elevando o reduciendo precios máximos, superficies máximas u otros parámetros, todo ello dentro de los límites establecidos en las leyes o los planes en la materia. Tal cosa podría ser aconsejable al menos en los municipios de áreas metropolitanas y los de mayor población, en los que el mercado inmobiliario presenta mayor complejidad y dinamismo. Bien arbitrada, esta flexibilidad podría contribuir a coordinar mejor las calificaciones de suelo y de vivienda y a hacerlas más eficaces y adaptables a la realidad socio-económica local del tiempo y lugar en el que han de ser aplicadas.

\section{DOS TIPOS DE TÉCNICAS DISPONIBLES}

Las técnicas arbitradas por nuestro Derecho urbanístico para favorecer la efectividad del derecho a la vivienda pueden agruparse en dos conjuntos: las relativas al régimen objetivo del suelo y las relativas al régimen estatutario del derecho de propiedad (pública y privada) sobre el suelo.

\subsection{Régimen objetivo del suelo}

\section{a) La calificación y la reserva de suelo con aprovechamiento lucrativo para vivienda protegida}

La posibilidad de conceptuar la vivienda de protección pública como un uso diferenciado del suelo y, por ende, como una calificación urbanística fue planteada primero por el planeamiento urbanístico y, después

5 Véanse, por ejemplo, los artículos 13 de la Ley 1/2010, de 8 de marzo, Reguladora del Derecho a la Vivienda en Andalucía y 12 de la Ley 9/2010, de 30 de agosto, del Derecho a la Vivienda de la Comunidad de Castilla y León. 
de ser anulada por los Tribunales por falta de cobertura legal ${ }^{6}$, obtuvo dicha cobertura en la Ley 8/1990, de 25 de julio, de Reforma del Régimen Urbanístico y Valoraciones del Suelo, de donde pasó al Texto Refundido de la Ley de Régimen del Suelo y Ordenación Urbana de 1992, que estableció que «el planeamiento urbanístico municipal podrá calificar terrenos para la construcción de viviendas sujetas a algún régimen de protección pública». Esta regla sería después declarada inconstitucional por falta de competencia del Estado en la Sentencia del Tribunal Constitucional 61/1997, de 20 de marzo, pero pasó de la ley estatal a las leyes urbanísticas autonómicas.

El principal problema de la calificación del suelo para uso residencial protegido -una vez superado el de la necesaria cobertura legal- es de carácter dogmático: se refiere a que la vivienda protegida no es, en propiedad, ni un uso del suelo materialmente diverso ni una tipología edificatoria necesariamente diferente de la vivienda libre, lo que permite dudar de su posible consideración como una calificación urbanística. Este problema ya fue aludido por el Tribunal Supremo en su jurisprudencia citada, cuando afirmó que «la habilitación que dimana del art. 33.2 de la Constitución, pasando por el art. 76 de la Ley del Suelo Texto Refundido de 1976 para delimitar urbanísticamente el derecho de propiedad en cuanto a su contenido, está referida a los aspectos o contenidos urbanísticos y no se puede extender al establecimiento de un régimen especial de construcción, enajenación o arrendamiento de los edificios; materia ésta que en la legislación sectorial específica es objeto de un tratamiento preciso a través de medidas de fomento y no de técnicas urbanísticas».

Sin embargo, aunque el urbanismo consista en la ordenación de los usos del suelo, no es ni ha sido nunca una ordenación exclusivamente física, ajena a los aspectos sociológicos, económicos o culturales de la ocupación de este recurso. Bien al contrario, es la expresión espacial o territorial de las diversas políticas socio-económicas que requieren utilizar el suelo ${ }^{7}$. Sirva como ejemplo que el Reglamento de Planeamiento de 1978 estableciera en su Anexo estándares diferenciados para equipamientos educativos (desagregados según niveles de enseñanza), deportivos y sociales sin que tampoco éstos tengan por qué ser física o tipológicamente diferentes entre sí, sino que atienden a necesidades sociales entre sí diversas, como también lo hacía la reserva de un porcentaje mínimo de la dotación de aparcamientos para usuarios minusválidos. En la medida en que el urbanismo ordena espacialmente las diversas necesidades sociales y económicas de utilización del suelo, puede sin duda atender también a las necesidades de vivienda asequible y disponer sus técnicas al servicio de la política de vivienda, del mismo modo que lo hace al servicio de la política industrial, comercial, social o educativa, por ejemplo.

Ahora bien, esta misma razón obliga a la coordinación entre la política sectorial o vertical de que se trate en cada caso y la horizontal de ordenación territorial y urbanística. Y la calificación urbanística de suelo para vivienda protegida ofrece una nueva oportunidad para la coordinación tan necesaria entre urbanismo y vivienda, pero también un reto ${ }^{8}$. Dos ejemplos pueden ilustrar este reto.

En primer lugar, deberán planificarse, programarse y disponerse los medios necesarios en la política de vivienda para poder calificar (y financiar, en su caso) tantos objetivos como requiera la ejecución del planeamiento en los sectores o ámbitos que contengan suelo calificado con este concreto destino: de lo contrario, la Administración estaría impidiendo al promotor el cumplimiento de sus deberes urbanísticos. Es decir, que una vez introducida la vivienda protegida como calificación urbanística, la coordinación entre planificación de vivienda y urbanística se hace más necesaria que nunca? ${ }^{9}$

6 Pueden verse las Sentencias del Tribunal Supremo de 11 de enero de 1985, 1 de junio de 1987, 17 de abril de 1991, 21 de mayo de 1991 y 5 de febrero de 1992. Esta última, por ejemplo, desestimó el recurso de apelación deducido por el Ayuntamiento de Madrid y la Comunidad de Madrid contra la Sentencia de 20-1-1990 del Tribunal Superior de Justicia de Madrid, por la que se había estimado parcialmente el recurso formulado por varios particulares contra el acuerdo de aprobación definitiva del Plan General de Ordenación Urbana de Madrid de 1985.

7 El propio Tribunal Supremo parece compartir este parecer cuando, por ejemplo, ha sancionado por razones de integración social la conformidad a Derecho de la denegación de una autorización urbanística de utilización del suelo no urbanizable para uso residencial en ejecución de un plan de erradicación del chabolismo, pues rechaza que pueda ser de interés público «la necesidad de emplazar en el medio rural a un colectivo del que se pretende su integración en el medio urbano» (STS de 11 de diciembre de 2003, F. J. 4. ${ }^{\circ}$ ).

8 A los problemas de coordinación entre las calificaciones de suelo de los planes urbanísticos y los programas de los planes de vivienda se han referido ya, por ejemplo, IGLESIAS GONZÁLEZ (2005: 537) y GARCÍA ÁLVAREZ (en LÓPEZ RAMÓN, coord., 2010: 395-396).

9 No está de más advertir, a estos efectos, que las políticas articuladas en los últimos planes de vivienda se han hecho más complejas y ambiciosas, pero no necesariamente mejor dotadas de recursos financieros, sobre los que ha incidido la crisis como se verá al final de este estudio. En ellas, la vivienda protegida ya no ocupa el papel protagonista casi exclusivo que tuvo históricamente, sino que convive -y comparte recursos- con otras actuaciones protegidas, como las ayudas directas a los demandantes de vivienda, las ayudas a la rehabilitación edificatoria y la renovación urbana, etc. 
Este problema se ha hecho evidente en el marco del Plan Estatal 2013-2016, que sólo califica y financia como vivienda protegida el parque de vivienda en alquiler edificada sobre suelo público. Es decir, que no contempla la vivienda protegida ni en venta, ni tampoco en alquiler sobre suelo privado ${ }^{10}$. Es cierto que dicho marco básico no impide a las Comunidades Autónomas seguir calificando -y, cuando dicha calificación conlleve alguna subvención, financiando con sus recursos propios-como vivienda protegida a la edificada sobre suelo privado incluso para su venta, como por ejemplo han hecho Andalucía ${ }^{11}$ o Cataluña ${ }^{12}$. Pero donde no se haga así, podría darse la paradoja de la imposibilidad de cumplir el destino del suelo, por inexistencia de tipologías de vivienda protegida sobre suelo privado ${ }^{13}$. Al igual que allí donde los objetivos de vivienda protegida establecidos en el plan de vivienda queden sensiblemente por debajo de las viviendas edificables en el suelo privado calificado para tal fin en el plan urbanístico, puede producirse un exceso de suelo calificado. Y allí donde un nuevo plan de vivienda altere sustancialmente los parámetros económicos de las viviendas protegidas (como su precio máximo en venta o alquiler o el importe de la subvención de que pueda beneficiarse) respecto de los vigentes o previstos al tiempo del plan urbanístico, puede darse la inviabilidad económica de algunas actuaciones de urbanización previstas en éste.

La disparidad competencial y temporal de los planes urbanísticos y de vivienda, de que me he ocupado en los apartados 3 y 4 , aumentan sin duda el riesgo de estos problemas y aconsejan insistir en la necesidad de coordinar a unos y otros instrumentos para que puedan cumplir sus fines comunes con eficacia.

En segundo lugar, ocurre a veces que los planes urbanísticos califican suelo para vivienda protegida con vigencia indefinida (sin perjuicio de su necesaria revisión transcurrido un plazo de tiempo, como prescriben la mayoría de leyes urbanísticas y, supletoriamente, los artículos 154 y siguientes del Reglamento de Planeamiento de 1978), mientras que la administración califica a la vivienda protegida sólo temporalmente, de conformidad con lo dispuesto en los planes de vivienda; de donde se sigue que, transcurrido el plazo de esta última calificación y en tanto no se revise o modifique la primera, el suelo destinado a vivienda protegida pasa a quedar ocupado por vivienda libre ${ }^{14}$. Para superar esta discordancia, el artículo 6 del Real Decreto 2066/2008, de 12 de diciembre, por el que se regulaba el Plan Estatal de Vivienda y Rehabilitación 20092012, previó que el régimen de protección pública de las viviendas y alojamientos a él acogidos fuera «de carácter permanente mientras subsista el régimen del suelo, si las viviendas y alojamientos hubieran sido promovidos en suelo destinado por el planeamiento a vivienda protegida, o en suelo dotacional público, y, en todo caso, durante un plazo no inferior a 30 años». Pero dicho plan ya no está vigente ${ }^{15} \mathrm{y}$ otros no contienen similares cautelas ${ }^{16}$.

10 Me refiero al ya citado Real Decreto 233/2013, de 5 de abril, por el que se regula el Plan Estatal de fomento del alquiler de viviendas, la rehabilitación edificatoria, y la regeneración y renovación urbanas, 2013-2016, en particular sus arts. 14 y 15.2 . Sin embargo, el Borrador del futuro Plan Estatal de Vivienda 2018-2021, publicado al tiempo de escribirse estas líneas, recupera el fomento del parque de vivienda en alquiler de titularidad privada en su art. 23 , si bien en el 25 mantiene la limitación de sus beneficiarios a los entes del sector público o del tercer sector.

11 El Decreto 141/2016, de 2 de agosto, por el que se regula el Plan de Vivienda y Rehabilitación de Andalucía $2016-2020$ introduce como novedad, en los términos de su preámbulo, «un programa de viviendas protegidas de precio limitado, con el objetivo de impulsar la promoción de viviendas en las reservas de los terrenos establecidas por la legislación urbanística para su destino a viviendas protegidas».

12 El Decreto 75/2914, de 27 de mayo, del Plan para el derecho a la vivienda de Cataluña sigue regulando las «viviendas con protección oficial» de promoción privada, tanto en venta como en alquiler (arts. 2.5 y 41 y ss.).

13 Obviamente, tal problema sólo se dará si la superficie de suelo calificada para vivienda protegida es superior a la de cesión obligatoria y gratuita a la Administración.

14 En opinión de Porto Rey (2001: 97-98), dicha vivienda queda en situación de fuera de ordenación, lo que acarrearía severas limitaciones en la propiedad de los terceros adquirentes de buena fe; mientras que para IGLESIAS GONZÁLEZ (en LÓPEZ RAMÓN, coord., 2010: 379-380) no hay discordancia o no tiene efecto alguno, porque la calificación del suelo para vivienda protegida se extingue con la construcción de dicha vivienda. Esta última opinión, sin embargo, es tributaria de la reticencia a considerar la VP como una genuina calificación del suelo por entender que no constituye un uso diferente, a la que me he referido en el cuerpo de este estudio. En mi opinión, sí hay un conflicto entre la duración de la calificación del suelo y la vivienda, que debería evitarse pero que, allí donde se dé, debe resolverse interpretativamente mediante el desplazamiento de la norma más general por la más específica y pro cive, que es la de duración de la calificación de la vivienda.

15 Una solución análoga (protección por 30 años «sin perjuicio de que si los suelos sobre los que se edifiquen las viviendas y alojamientos protegidos están calificados urbanísticamente con el uso pormenorizado de vivienda protegida, se mantendrá dicho régimen legal mientras permanezca la calificación del suelo») es la que rige en Andalucía, en virtud del art. 25 del citado Decreto 141/2016, de 2 de agosto, por el que se regula el Plan de Vivienda y Rehabilitación de Andalucía 2016-2020.

16 En Castilla y León, por ejemplo, la duración de la protección es siempre de 15 años (art. 50 de la Ley 9/2010, de 30 de agosto, del Derecho a la Vivienda de la Comunidad de Castilla y León) y en Cataluña, el Decreto 75/2914, de 27 de mayo, del Plan para el derecho a la vivienda establece la calificación por el plazo de treinta años (quince si se trata de municipios sin demanda residencial fuerte y acreditada) en el caso de promociones en suelo de reserva urbanística con destino a vivienda protegida y si se obtienen ayudas 
Una vez asumida y normalizada la calificación del suelo para vivienda protegida, el siguiente paso dado por el legislador urbanístico fue no ya habilitar, sino imponer al planeamiento territorial y urbanístico la reserva de suelo para este uso. La primera Comunidad Autónoma que lo hizo fue la del País Vasco. Ley 4/1990, de 31 de mayo, de Ordenación del Territorio de la Comunidad Autónoma del País Vasco (en adelante, LOT) impuso en su artículo 6.7 como determinación mínima de las Directrices de Ordenación del Territorio (en adelante, DOT) «la cuantificación de la necesidad de vivienda, especialmente de las de protección oficial, en las diferentes áreas o zonas del territorio y establecimiento de los criterios de localización de las mismas y de los parámetros a tener en cuenta por los instrumentos de ordenación urbanística». En desarrollo de las DOT, también los Planes Territoriales Parciales debían cuantificar las superficies de suelo que hayan de reservarse en todo caso con destino a la construcción de viviendas de protección oficial (art. 12.1.f) LOT).

Posteriormente, la Ley 17/1994, de 30 de junio, de medidas urgentes en materia de vivienda y de tramitación de los instrumentos de planeamiento y gestión urbanística (más conocida como Ley Maturana por el Consejero del Gobierno vasco que la impulsó), estableció en su Capítulo I unos «estándares de viviendas de protección pública» cifrados en el $20 \%$ del aprovechamiento total residencial previsto en operaciones sistemáticas de reforma interior en suelo urbano y el $65 \%$ del total residencial previsto en suelo urbanizable programado para cada uno de los cuatrienios y en suelo apto para urbanizar. Tales estándares fueron establecidos como de obligado cumplimiento por imperio de la Ley para el planeamiento urbanístico de los Municipios de más de 7.000 habitantes, atribuyéndose al Consejero competente en materia de urbanismo y vivienda las potestades, de un lado, de autorizar excepcionalmente porcentajes inferiores «siempre que se acredite el cumplimiento global de los estándares mínimos» y, de otro lado, de extender dicha obligación a algunos de los restantes Municipios ${ }^{17}$.

Siguiendo este primer precedente, la reserva legal de suelo para vivienda protegida ya rige en todas las Comunidades Autónomas y no se han apreciado efectos inflacionarios en su implantación, pese a que en algunos territorios tiene un nivel muy elevado. La cuestión es que en otros territorios no regía, hasta hace una década, reserva legal alguna lo que, aparte de afectar a la unidad de mercado (tengamos en cuenta que esta reserva oscilaba entre el $75 \%$ y el $0 \%$ según Comunidades Autónomas), dificultaba sobremanera la promoción de vivienda asequible, porque el mercado no provee terrenos urbanos a valores de repercusión compatibles con la vivienda protegida justo allí donde ésta más falta hace. De ahí la inclusión de un estándar básico en la Ley de Suelo, actualmente cifrado por el Texto Refundido de la Ley de Suelo y Rehabilitación Urbana en el $30 \%$ de la edificabilidad residencial de las actuaciones de nueva urbanización y el $10 \%$ en las de reforma o renovación de la urbanización existente [art. 20.1.b)] ${ }^{18}$.

El destino de esta reserva es la "vivienda sujeta a un régimen de protección pública que, al menos, permita establecer su precio máximo en venta, alquiler u otras formas de acceso a la vivienda, como el derecho de superficie o la concesión administrativa». La Ley utiliza una fórmula tan abierta con el propósito de respetar las competencias autonómicas exclusivas sobre vivienda y urbanismo. En efecto, el objeto del precepto no es configurar una determinada política de vivienda, sino establecer un estándar mínimo y básico en la utilización del suelo residencial, de forma que una parte proporcional del mismo cumpla una función social cual es destinarse a vivienda asequible, lo que delimita el contenido de la propiedad de tales terrenos al servicio de la efectividad del derecho contenido en el artículo $47 \mathrm{CE}$.

Para asegurar esa función, el legislador estatal se limita a exigir que ese producto inmobiliario tenga establecido un precio máximo. En lo demás, es el legislador sectorial quien debe determinar las características de dicho producto (superficie y demás características físicas, precio, formas de adquisición o de acceso a su disfrute, sujetos legitimados para acceder al mismo, etc.) así como la proporción exigible de suelo desti-

directas (art. 47.1). En el otro extremo, la Ley 3/2015, de 18 de junio, de Vivienda del País Vasco establece en su art. 29 como regla general la calificación permanente de la vivienda protegida.

17 En desarrollo de esta Ley, el Decreto 142/1997, de 17 de junio, estableció diversas reglas de ejecución de los estándares, y en particular la precisión de que se aplicasen en suelo urbano «sobre el incremento residencial previsto por el planeamiento en edificios de nueva planta, con respecto al aprovechamiento existente» y en suelo urbanizable para «cada sector de suelo urbanizable programado o apto para urbanizar».

18 La previsión de esta reserva no sólo en las actuaciones de nueva urbanización, sino igualmente en las actuaciones de reforma o renovación del suelo urbanizado, así como los deberes de realojamiento y retorno previstos indistintamente para cualesquiera actuaciones de transformación urbanística, pueden servir -si tienen un adecuado desarrollo por la legislación urbanística- para evitar el riesgo de segregación espacial justamente contrario al de la degradación o depauperación de los barrios, que es el conocido con el anglicismo «gentrificación» (del original gentrification), es decir, la expulsión de la población residente y su sustitución por otra de mayor poder adquisitivo atraída por la actuación de transformación urbanística. Un problema poco tradicional pero emergente en nuestras ciudades (LEAL MALDONADO, 2002: 68). 
nado a él (con el mínimo del 30 ó $10 \%$ ), cuáles deban ser los ámbitos de referencia para aplicar la reserva y aquéllos en que quepa exceptuarla, etc., con una amplísima libertad de configuración. Todo ello diferencia sustancialmente a la reserva básica del artículo 20 del actual Texto Refundido, cuya constitucionalidad confirmó la STC 141/2014, de 11 de septiembre, de la regla estrictamente urbanística contenida en su día en el artículo 98.3 del Texto Refundido de 1992 y que fuera declarada inconstitucional por invasión competencial por la STC 61/1997, de 20 de marzo.

Conviene tener presente que, en la década previa a la promulgación de la Ley, los precios del suelo habían escalado de forma insostenible ${ }^{19} \mathrm{y}$ habían hecho evidente su erección como principal barrera contra la promoción de vivienda protegida en España. Así las cosas, resulta más eficaz para favorecer esta actividad promocional la garantía de una oferta suficiente de suelo a valor de repercusión tasado, que no las subvenciones para la compra y urbanización de suelo, cuya regulación básica estatal al amparo del artículo 149.1.13. ${ }^{a}$ CE en sucesivos planes de vivienda nadie cuestionó desde los años ochenta del siglo pasado.

Además, España afronta retos sociales mayores, como el envejecimiento de la población, la emancipación tardía por la dificultad de los jóvenes de acceder al empleo y al crédito, o la inmigración masiva. Para hacerles frente, nuestra política de vivienda se vale no sólo, pero sí principalmente de la vivienda protegida. Por ello, debemos estar especialmente atentos a evitar que ésta se concentre en grandes actuaciones sociales segregadas espacialmente de las áreas residenciales de mercado libre: debemos favorecer una zonificación inclusiva (inclusionary zoning) y la mezcla social (mixité sociale) con la combinación de vivienda libre y protegida ${ }^{20}$, si no queremos volver a incurrir en viejos errores de las políticas de vivienda de los años 50 y 60 del siglo xx que intentamos corregir con las políticas urbanas de hoy ${ }^{21}$.

\section{b) La calificación y la reserva de suelo dotacional para uso residencial}

El siguiente y, por ahora, último paso dado por la legislación urbanística en España ha sido el de considerar el uso residencial de carácter social o protegido no ya como un aprovechamiento lucrativo diferenciado, sino como un uso dotacional público del suelo. Culmina así la evolución descrita dando entrada al alojamiento o la vivienda asistencial, de inserción o, en general, protegida entre los equipamientos públicos que pueden prescribir los planes urbanísticos en las ciudades.

Es hora de asumir que la vivienda social pública puede y debe ser una dotación urbana más, al igual que lo son las plazas, las calles, las escuelas, los centros de salud o de la tercera edad. ¿Tiene sentido que los espacios "de día», ya sean ocupacionales o de ocio, de los colectivos socialmente vulnerables como pobres, ancianos o jóvenes sean pacíficamente admitidos como equipamientos y los espacios «de noche» 0 residenciales no? Si la habitación, el alojamiento o la residencia de las personas en situación de necesidad es un servicio público de carácter social, el inmueble destinado a prestarlo debe poder ser considerado -con independencia de su tipología edificatoria- como un equipamiento público de carácter social.

$\mathrm{Y}$, al igual que hemos visto unos párrafos más atrás con la calificación de la vivienda protegida como aprovechamiento lucrativo diferenciado, se han dado dos posibilidades: o la mera habilitación al planeamiento o la imposición al mismo de estándares legales mínimos.

La primera Comunidad Autónoma en dar este último paso fue la de Madrid, cuya Ley 9/2001, de 17 de julio, del Suelo, instauró en su artículo 36 la «red de viviendas públicas o de integración social» entre las redes públicas supramunicipales de servicios. Significa esto que los suelos destinados a ellas pueden adquirirse por cesión obligatoria y gratuita cuando se integren en un ámbito o unidad de ejecución sistemáticos, de conformidad con lo previsto en el artículo 90 y, en caso contrario, por ocupación directa o por expropiación forzosa. Hasta 2010, la Ley establecía además estándares legales mínimos para la cesión, que cuantificaba en su artículo 91 en la tercera parte de las cesiones a la Comunidad de Madrid para el sistema de redes públicas supramunicipales, que eran a su vez de 20 metros cuadrados de suelo por cada 100 metros cuadrados construidos de cualquier uso 22 .

19 Entre 1998 y 2005, los precios del suelo urbano se incrementaron un 500 \%, según el Banco de España.

20 Estos han sido los objetivos perseguidos con medidas similares adoptadas en los últimos tiempos en Estados Unidos y Francia, respectivamente. Sobre estos casos, pueden verse PONCE SOLÉ, 2001, y los estudios monográficos de SÁNCHEZ DE MADARIAGA, 1998, y TEJEDOR BIELSA, 1998. Más ampliamente, sobre la función de equilibrio territorial de la vivienda social, PONCE SOLÉ, 2004: 163.

21 Así lo había defendido ya en el Estudio preliminar a PAREJO Y FERNÁNDEZ, 2009: 62.

22 Esta determinación legal se ha visto afectada por las Leyes 9 y 10/2010, de 23 de diciembre, y ahora el precepto no sólo no contempla tal estándar, sino que además establece, por excepción a la regla general en materia de redes públicas, que «los suelos 
Posteriormente, la Ley Foral 35/2002, de 20 de diciembre, de Ordenación del Territorio y Urbanismo de Navarra incluyó en su artículo 53 que, en los sectores de suelo urbanizable, el planeamiento deberá definir una reserva de suelo, con el carácter de dotación supramunicipal, que en la redacción actualmente vigente está circunscrita a los sectores de uso predominante residencial y debe tener una superficie no inferior a 3 metros cuadrados por cada 100 metros cuadrados construidos de uso residencial, que tendrá la condición de solar, la cual se calificará para la construcción de viviendas u otros usos residenciales de titularidad pública. Cataluña incorporó asimismo a su Texto Refundido de la Ley de Urbanismo aprobado por Decreto Legislativo $1 / 2005$, de 26 de julio, la previsión según la cual «el planeamiento urbanístico general puede prever como sistemas urbanísticos reservas de terrenos destinados a viviendas dotacionales públicas» (art. 34.3) fijando, en este caso, su cuantía en el 5 por ciento, como máximo, de la reserva global del municipio para equipamientos públicos locales.

En fin, otras leyes fueron siguiendo también este camino hoy ya bastante transitado, como la Ley 1/2006, de 7 de febrero, de modificación del Decreto Legislativo 1/2000, de 8 de mayo, por el que se aprueba el Texto Refundido de las Leyes de Ordenación del Territorio y de Espacios Naturales de Canarias (disposición adicional primera.1), la Ley 2/2006, de 30 de junio, de Suelo y Urbanismo del País Vasco (artículo 54) y la Ley 6/2008, de 19 de junio, de Medidas Urgentes en Materia de Vivienda y Suelo, por la que se modifica la Ley 9/2002, de 30 de diciembre, de Ordenación Urbanística y Protección del Medio Rural de Galicia (artículo único, apartados uno y dos, que modifican sus artículos 22 y 47 respectivamente), etc.

En la medida en la que se están consolidando el concepto de los alojamientos o viviendas dotacionales y el principio de que la vivienda social debe ofrecerse preferentemente en régimen de alquiler u otro derecho temporal de uso, no en venta, la cuestión que surge de esta evolución es la de si la calificación y reserva del suelo dotacional para vivienda se irá configurando progresivamente ya no como meramente complementaria, sino como sustitutiva de la calificación y reserva de suelo lucrativo para vivienda protegida.

Tal hipótesis serviría para concebir a la vivienda social como un equipamiento urbano, antes que como un producto inmobiliario más, cuya oferta se quiere garantizar mediante su inserción en el sistema de cargas de la propiedad inmobiliaria. Pues, con independencia de las discutibles críticas que esta última concepción siempre ha recibido desde la perspectiva de la justicia, lo cierto es que siempre ha planteado problemas desde la perspectiva de la eficacia. Y tendría la doble ventaja de, de un lado, $\left(1 .^{\circ}\right)$ contribuir decididamente a la formación de un parque público (sin perjuicio de su gestión privada, con o sin ánimo de lucro) y estable de suelo destinado a alojamiento y/o vivienda social en alquiler y, de otro lado, $\left(2 .^{\circ}\right)$ evitarles a los propietarios del suelo tanto la imposición de rígidas limitaciones de destino de su suelo residencial, como la doble imposición de cargas de cesión obligatoria y gratuita de suelo -dotacional y lucrativo- para usos de alojamiento o vivienda social.

\subsection{Régimen estatutario de la propiedad}

\section{a) La participación de la comunidad en las plusvalías y los patrimonios públicos de suelo}

La participación de la comunidad en las plusvalías viene articulándose en España mediante la atribución ex lege a la Administración de un porcentaje del aprovechamiento urbanístico desde 1975. La singularidad de la técnica empleada en España no debe engañarnos ni permite olvidar que los países de nuestro entorno también han articulado figuras con el mismo fin de procurar el rescate público de una parte de las plusvalías urbanísticas, ya se denominen planning gains, plafond légal de densité o concessione edilizia. Dado que parte de la plusvalía urbanística se financia por todos al valerse de infraestructuras externas o preexistentes de transporte y de agua no costeadas por la actuación, y que nos genera nuevo gasto público en mantenimiento de infraestructuras y prestación de servicios públicos, se trata de garantizar que una parte razonable y proporcionada de ella revierta asimismo directamente en la sociedad, como manda la Constitución, para compensar no sólo estas «externalidades» negativas o impacto económico, sino también su impacto ambiental ${ }^{23}$.

Ahora bien, el hecho mismo de su inserción en el artículo 47 de la Constitución parece sugerir que la voluntad constituyente no era sólo arbitrar una técnica de distribución de la riqueza inmobiliaria, en desarrollo

\footnotetext{
integrantes de las redes supramunicipales cedidos a la Comunidad de Madrid tendrán la condición de bienes patrimoniales salvo que una Ley les otorgue expresamente el carácter de bienes de dominio público».

${ }_{23}$ BAÑO LEÓN ya llamó la atención sobre esta idea de justicia distributiva, que el autor conectó con el principio del Derecho medioambiental «quien contamina paga» (2001: 45).
} 
del principio más general de subordinación de toda la riqueza al interés general del artículo 128 de la propia Constitución, sino también un instrumento al servicio de las políticas de suelo y vivienda.

Esta vinculación constitucional de la participación en las plusvalías a las políticas de suelo y vivienda justifica que la Ley de Suelo haya considerado básico exigir que los bienes, derechos y recursos adquiridos por su vía (incluidos los ingresos obtenidos mediante la enajenación de los terrenos que los integran o su sustitución por dinero) integren un patrimonio público de suelo, que es un patrimonio separado afectado a determinados fines por imperio de la Ley (art. 51 TRLSRU) ${ }^{24}$. Primaria y necesariamente, esta masa patrimonial debe ser empleada para la promoción de vivienda protegida, sin perjuicio de su posible dedicación a otros usos complementarios que especifiquen las leyes autonómicas (art. 52.1 TRLSRU).

La voluntad del legislador estatal de dar cumplido desarrollo al mandato constitucional en este punto se observa también en la forma que utiliza para determinar el rango de esta participación de la comunidad de la plusvalía: ya no la fija mediante una horquilla de mínimo y máximo universales, sino mediante una horquilla general de entre el 5 y el $15 \%$, que la legislación sobre ordenación territorial y urbanística podrá respectivamente reducir (hasta el $0 \%$ ) o ampliar (hasta el $20 \%$ ) excepcionalmente «para las actuaciones o los ámbitos en los que el valor de las parcelas resultantes sea sensiblemente inferior o superior, respectivamente, al medio en los restantes de su misma categoría de suelo» [art. 18.1.b) TRLSRU]. Y es que la Constitución manda que la comunidad participe en las plusvalías urbanísticas, no en el aprovechamiento urbanístico, y a iguales aprovechamientos pueden corresponderles muy distintas plusvalías, dependiendo de las cargas que haya que levantar para generar ese aprovechamiento.

De algún modo, esta previsión traslada a la legalidad lo que era práctica habitual en el urbanismo convencional. Y aprovecha la ocasión para ponerle coto. En efecto, en España se había hecho habitual que las Administraciones públicas condicionaran la ordenación de actuaciones urbanísticas, especialmente las más lucrativas, a la firma de convenios en los que los propietarios y/o el promotor asumían más cargas que las legales. Una práctica que ha dado pie en ocasiones a desviaciones de poder (al utilizar potestades de ordenación y ejecución urbanísticas con finalidades financieras) e incluso a ilícitos punibles (prevaricación, cohecho, etc.). Esta habilitación del legislador estatal al autonómico para modular la participación de la comunidad en las plusvalías permite predeterminar normativamente esta modulación, regulando de forma general en qué casos procede y con qué límites, lo que hace innecesario acudir a la vía convencional dentro de tales límites. Y fuera de ellos, «los convenios o negocios jurídicos que el promotor de la actuación celebre con la Administración correspondiente, no podrán establecer obligaciones o prestaciones adicionales ni más gravosas que las que procedan legalmente en perjuicio de los propietarios afectados. La cláusula que contravenga estas reglas será nula de pleno Derecho» (art. 9.8 TRLSRU).

Pero, como también se ha dicho, la participación de la comunidad en las plusvalías no es sólo una técnica de distribución de la riqueza inmobiliaria, sino también una herramienta de las políticas de suelo y vivienda, que puede ser utilizada por el legislador para fomentar la promoción privada de actuaciones urbanísticas de interés general, reduciendo el porcentaje de la participación pública en el aprovechamiento cuando pueda arriesgar la viabilidad económica de las mismas. Así puede ocurrir, por ejemplo, con las actuaciones de renovación urbana en el suelo ya urbanizado. La intervención en el suelo urbanizado se ve condicionada por muchas más situaciones consolidadas que la transformación del suelo urbanizable: mayor fragmentación de la propiedad, más edificaciones a demoler y/o conservar y rehabilitar, mayor población a realojar y retornar, etc., lo que limita comúnmente el ius variandi, las plusvalías y el margen para distribuirlas equitativamente con las cargas. Se explica así, en consecuencia, que la propia Ley estatal permita al planeamiento eximir con carácter excepcional de cesiones de suelo a las actuaciones sobre zonas con un alto grado de degradación o de sustitución de infravivienda (art. 18.4 TRLSRU) o que el Texto Refundido de la Ley de Urbanismo de Aragón (Decreto Legislativo 1/2014, de 8 de julio) le permita, excepcionalmente y de forma específicamente motivada, ampliar la participación de la comunidad en las plusvalías hasta un máximo del $20 \%$ tanto en suelo urbano como urbanizable, pero sólo reducirla e incluso eliminarla en las actuaciones de rehabilitación

24 El Tribunal Constitucional rechazó el carácter básico y, en consecuencia, declaró inconstitucional el precedente artículo 277 del Texto Refundido de 1992 porque «la concreción con carácter básico de cuáles hayan de ser los bienes que lo integran no responde ya de forma inmediata y directa a la planificación general de la actividad económica» (STC 61/1997, de 20 de marzo, F. J. 36. ${ }^{\text {) }}$. Pero este precepto se aparta de dicho precedente, porque ya no tiene dicho alcance concreto y omnicomprensivo, sino que se limita a establecer una regla singular de conexión entre dos instituciones de competencia estatal, los patrimonios públicos de suelo y la participación de la comunidad en la plusvalía, para asegurar la subsistencia de la primera y evitar la defraudación de la función constitucional de la segunda. Por esta razón, fue declarado constitucional por la STC 141/2014, de 11 de septiembre [FJ 11.A)]. 
del suelo urbano no consolidado (artículos 127 y 128). De esta forma, hace uso de la habilitación legal estatal para configurar legalmente una técnica de fomento de la renovación urbana.

Simétricamente, a las actuaciones urbanísticas residenciales en suelo urbanizable de baja densidad y tipologías edificatorias unifamiliares, pareadas o adosadas, que tanto han proliferado en España en las últimas décadas, muchas veces asociadas a equipamientos deportivos como campos de golf y a complejos comerciales o turísticos, y tantas veces eximidas del cumplimiento de la reserva de suelo para vivienda protegida, se les podrá incrementar la participación de la comunidad en sus plusvalías cuando éstas sean sensiblemente superiores a las de otras actuaciones o ámbitos. Llegamos, pues, a la conclusión de que la modulación posibilitada por el legislador estatal -si es bien articulada por el legislador autonómico y bien aprovechada por el planificador urbanístico- puede ser un paso para implantar el principio ambiental «quien contamina paga» en el urbanismo español, de forma que la participación de la comunidad en la plusvalía sea mayor en las actuaciones menos sostenibles (nuevas urbanizaciones extensivas y de baja densidad) y menor en las más sostenibles (actuaciones de renovación urbana de mayor interés social).

Por otro lado, la Ley estatal de Suelo ha trabado esta participación pública en la plusvalía con la reserva de suelo para vivienda protegida, tratada en el apartado anterior, de forma que no sea duplicativa, sino simbiótica. La reserva es un estándar objetivo para la ordenación urbanística, mientras que la participación de la comunidad en la plusvalía es un deber subjetivo de prestación patrimonial. La primera garantiza la suficiencia de suelo para un producto inmobiliario de interés social, que ya asumimos como un equipamiento urbano más. La segunda establece un reparto de plusvalías en forma de atribución de una parte de los suelos (o de su valor) a la Administración. Ahora bien, dado que esta adjudicación de suelo no persigue fines financieros sino coadyuvar a las políticas de suelo y vivienda, la Ley introduce un límite específico a la autonomía para decidir qué suelos deban ser adjudicados u optar por el pago de su equivalente en dinero: cuando coincidan reserva y participación de la comunidad en la plusvalía, esta participación debe cumplirse con los suelos destinados a vivienda protegida, total o parcialmente hasta donde alcancen los suelos reservados a dicho uso por el plan [art. 18.1.b) in fine TRLSRU]. De esta forma, se aprovechan las sinergias entre las dos instituciones y se evita la defraudación de su función legal.

Las dos críticas más habituales contra la atribución a la Administración de un porcentaje del aprovechamiento urbanístico sostienen que es un tributo encubierto, cuyo único fin es la financiación de los Ayuntamientos, y que repercute negativamente sobre el precio de las viviendas. Sin embargo, empezando por esto último, su supuesto impacto inflacionario no se ha observado ni cuando se implantó el $10 \%$ en 1975, ni cuando se subió al $15 \%$ en 1990, ni finalmente cuando bajó al $10 \%$ en $1996^{25}$. Y no se trata de un tributo ni es asimilable a él, sino que es una prestación patrimonial de carácter público de las previstas en el apartado 3 del artículo $31 \mathrm{CE}$. En efecto, su finalidad no es recaudatoria -el «sostenimiento de los gastos públicos» a que se refiere el apartado 2 del citado artículo 31- sino instrumental de las políticas públicas de suelo y vivienda, y tampoco grava la "capacidad económica» de su sujeto pasivo, sino que es independiente de ella porque persigue subordinar la riqueza al interés general (art. 128.1 CE), en este caso la riqueza en que consisten las plusvalías que genera la acción urbanística de los entes públicos, en las que debe participar la comunidad por imperativo constitucional (art. $47 \mathrm{CE}$ ).

Es cierto que en España se han dado en ocasiones malas prácticas en la gestión de los patrimonios públicos de suelo ${ }^{26}$, pero no lo es menos que buena parte de la vivienda protegida promovida en las últimas décadas se ha hecho sobre esos suelos y que la propia Ley adopta medidas novedosas para asegurar que se cumpla efectivamente su uso de interés social. Es esto importante: de nada sirve establecer reservas o estándares si después el uso de interés social de los suelos o el destino de los patrimonios que integran no se cumple efectivamente. Por ello la Ley combina flexibilidad en la gestión patrimonial y en su destino con rigor en la exigencia del cumplimiento efectivo de su finalidad.

La flexibilidad se observa, en primer lugar, en el artículo 51.2 del Texto Refundido a propósito de las facultades de gestión, que se amplían siempre que se trate de la «autorreinversión» propia de un «fondo ro-

25 La explicación puede encontrarse en las muchas voces que afirman que es el precio del suelo el que viene determinado por el precio de la vivienda y no al revés. En este sentido, por todos, HERCE, LÓPEZ, RODRÍGUEZ y TALTAVULL, 2005: 82-83.

26 Que han obligado al Tribunal Supremo a recordar reiteradamente la «imposibilidad de que los Ayuntamiento conviertan el Patrimonio Municipal del Suelo en fuente de financiación de cualesquiera necesidades municipales». Por todas, pueden consultarse las SSTS de 2 de noviembre de 1995, 14 de junio de 2000, 25 de octubre de 2001, 31 de octubre de 2001, 2 de noviembre de 2001, 29 de noviembre de 2001, 27 de junio de 2002, 7 de noviembre de 2002 y 27 de junio de 2006. 
tatorio de retroalimentación continua» para optimizar su aprovechamiento ${ }^{27}$. El anterior régimen legal exigía que los ingresos obtenidos mediante la enajenación de terrenos o la sustitución del aprovechamiento correspondiente a la Administración por su equivalente metálico se destinasen a la conservación y ampliación del mismo (art. 276.2 TRLS 1992), posibilidades a las que la nueva Ley añade ahora otras dos: dedicarlos a la administración del propio patrimonio -siempre, claro está, que sólo se financien gastos de capital, no corrientes- $\mathrm{o}$, lo que es más importante, a los usos propios de su destino, como por ejemplo la construcción de viviendas protegidas. $Y$ decimos que es importante porque es frecuente que los Ayuntamientos cuenten con más suelo que dinero para promover vivienda protegida, lo que dificulta su destino efectivo a este uso, salvo que desistan de la promoción pública y enajenen los terrenos a terceros o, en el nuevo marco legal, que enajenen algunos terrenos y afecten su precio a la promoción de las viviendas en otros.

Flexibilidad también en el destino de los patrimonios, habida cuenta de la diversidad de las prioridades a que puede dar lugar la combinación de la autonomía de la Administración titular con el localismo y la mutabilidad de los mercados de suelo. De ahí que el legislador básico haya permitido al planificador destinar sus bienes y recursos a diversos fines de interés general territorial y urbanístico (art. 52.1) cuando así lo prevea la legislación urbanística especificando los fines admisibles ${ }^{28}$.

El rigor de la Ley, por su parte, se manifiesta precisamente en la disciplina a que somete estas enajenaciones, cuando prohíbe a las Administraciones subastar o vender el suelo por encima del valor máximo de repercusión para vivienda protegida, cuando ése sea su uso (art. 52.2 TRLSRU), para impedir que un suelo que se obtiene gratuitamente, integra un patrimonio separado y está objetivamente vinculado a determinados usos de interés social y precio tasado pueda acabar siendo subastado al alza y calentando el mercado.

Con todo, esta regla pone coto al problema pero no lo elimina. Las Administraciones públicas seguirán pudiendo enajenar onerosamente terrenos que han adquirido gratuitamente por imperio de la Ley para cumplir una función social, lo que seguirá haciendo posible que esas enajenaciones, aunque sean a valor de repercusión de vivienda protegida en su parte de uso residencial, incurran en desviación de poder por perseguir finalidades financieras antes que de política de vivienda y suelo. Para evitarlo, quizás debería estudiarse en el futuro prohibir la enajenación definitiva de estas parcelas adquiridas gratuitamente en virtud de una carga general de la propiedad del suelo, de manera que su gestión patrimonial deba hacerse siempre mediante negocios jurídicos limitados temporalmente y, por ello, reversibles, como el arrendamiento o la constitución de derechos reales limitados (superficie u otros) ${ }^{29}$. Por esta vía, se estabilizaría la generación de patrimonios públicos de suelo para fines sociales, sin perjuicio de su explotación y gestión privadas; se superaría el complejo de Pandora ${ }^{30}$ que rodea hoy a la institución en España; y se dotaría a las Administraciones de poderosas herramientas en el largo plazo para las políticas urbanas.

La misma finalidad de control se persigue en la Ley al prever la constancia registral tanto de la calificación urbanística para uso de vivienda protegida de los terrenos, en su caso (art. 27.2 TRLSRU), como de la limitación de precio o cualquier otra limitación, obligación, plazo o condición de destino que se haga constar en su enajenación, para lo cual la Ley exceptúa la vieja prohibición de acceso al Registro que contiene el artículo 27 de la Ley Hipotecaria (art. 52.3 TRLSRU). Es lógico que así se haga: cuando hablamos de patrimonios públicos de suelo, las limitaciones, los plazos o las condiciones impuestos en los negocios jurídicos de enajenación no son mera expresión de la autonomía de la voluntad de los contratantes, sino técnicas de control o de garantía de la eficacia de políticas públicas inmobiliarias, a cuyo servicio bien puede ponerse la función pública de la publicidad registral ${ }^{31}$.

27 Expresiones que utiliza el Tribunal Supremo en sus Sentencias de 2 de noviembre de 1995 y de 31 de octubre de 2001, por ejemplo.

28 Ahora bien, me refiero aquí a la flexibilidad, pero ya no a la posibilidad de defraudación de dicho destino (que justifica su consideración como un patrimonio separado) después introducida en la regla del art. 52.5, que permite excepcionalmente destinarlo a reducir la deuda comercial y financiera del Ayuntamiento (bajo una condición de reintegro de incierto cumplimiento). Dicha regla, en mi opinión, defrauda el espíritu de la ley y arrumba los esfuerzos interpretativos y aplicativos de la jurisprudencia a que me he referido en la nota 24.

29 El preámbulo de la Ley 19/1975, de 2 de mayo, de Reforma de la Ley sobre Régimen del Suelo y Ordenación Urbana ya postulaba que «desde la perspectiva de los patrimonios públicos de suelo, el derecho de superficie puede y debe ser un instrumento mediante el que, cada vez más, se procure que el derecho de propiedad sobre el suelo urbano, una vez que entre en la esfera patrimonial de la Administración, no salga de la titularidad pública; el incremento no sólo en el espacio, sino en el tiempo, de los patrimonios públicos de suelo, debe seguir siendo pieza clave de la política urbanística».

30 Según Julio VINUESA, José MARÍA DE LA RIVA y Antonio J. PALACIOS «la venta de suelo difícilmente obtenido para el patrimonio público es un permanente tejer y destejer que, además de transferir las plusvalías de bienes públicos a particulares, convierte en estructurales la escasa disponibilidad de suelo y los emplazamientos de deficiente calidad residencial» (2009: 512).

31 Luciano PAREJO y Gerardo ROGER FERNÁNDEZ, 2009: 479. 


\section{b) El derecho de superficie}

La enajenación del pleno dominio del suelo a título oneroso, aunque sea a valores de repercusión para vivienda protegida, tiene un precio que hace difícilmente rentable la promoción de vivienda protegida en alquiler $u$ otras formas de disfrute temporal. Por eso, los países de mayor tradición en la promoción de vivienda social en alquiler nos aventajan en la práctica de constituir derechos reales de carácter temporal sobre suelos públicos, a cuyo vencimiento revierten a la Administración. Esta alternativa tiene una triple ventaja: primero, favorece la promoción privada (no necesariamente lucrativa) de vivienda social al abaratar el precio por el que el promotor accede al uso y disfrute del suelo, permitiendo una amortización más rápida de su inversión; segundo, el promotor superficiario puede ceder al usuario final la vivienda en alquiler o en derecho de superficie, es decir, con derechos limitados temporalmente que favorecen la rotación del parque de vivienda protegida y, por tanto, la eficacia misma de la política de vivienda y, por último, aumenta también la eficacia y el control público en las políticas de suelo al conservar sobre él la Administración ciertas facultades dominicales.

El fomento del derecho de superficie como herramienta de las políticas de suelo y vivienda es una vieja aspiración del legislador español. Ya la exposición de motivos de la Ley de 12 de mayo de 1956, de Régimen del Suelo y Ordenación Urbana, advertía que «el fomento de la edificación no precisa, ni a veces aconseja, la enajenación de los terrenos: basta la constitución del derecho de superficie. La experiencia extranjera muestra las intensas posibilidades de esta figura jurídica que a la vez que facilita la construcción, evita la especulación en edificios y terrenos y reserva el aumento de valor del suelo para el propietario. De aquí que se admita la constitución del derecho de superficie por entidades públicas y por particulares.».

Por estas razones, la Ley de Suelo de 1956 configuró un régimen especial de carácter estatutario y delimitado por su singular función social, no sólo para el derecho de propiedad, sino también para el derecho de superficie, que tenía hasta entonces una regulación puramente incidental en el Código civil. De entre los distintos derechos reales limitados previstos en el Código -usufructo, censos, etc.- el de superficie se adaptaba perfectamente, por su objeto y contenido, al tipo de negocio jurídico que el legislador del suelo quería fomentar: la cesión estable pero temporal de la edificabilidad a un tercero, quien tendría la facultad pero también el deber de edificar y la posibilidad de usar o disfrutar lo edificado hasta amortizar sobradamente su inversión, pero sin incentivos para orientar su actividad hacia la apropiación de plusvalías expectantes o futuras, dada la reversión al superficiante de todo el objeto del derecho a su término.

Sin embargo, este derecho real no ha ganado, en el medio siglo transcurrido desde entonces, el protagonismo que para él ha reivindicado el legislador y que de hecho tiene en otros países ${ }^{32}$.

A ello pueden haber contribuido varias causas: Una es el coste de oportunidad para el propietario del suelo de enajenar los terrenos o las viviendas en derecho de superficie, obteniendo una contraprestación inferior a la que podría percibirse con la plena enajenación. Por lo que se refiere en particular a las Administraciones públicas, la consideración misma de este coste de oportunidad pone en evidencia que la gestión de su patrimonio inmobiliario ha primado históricamente los intereses generales financieros sobre los de la política de vivienda. Una desviación de poder arraigada y difícil de corregir, aunque el legislador lo está intentando al menos en los últimos años, como ya se ha expuesto más atrás. Otra posible causa son las dificultades del superficiario para financiar su actividad promotora, ya que tradicionalmente esta actividad se ha financiado mediante crédito hipotecario $y$, aunque el derecho de superficie puede ser hipotecado (art. $107.5 .^{\circ}$ de la Ley Hipotecaria), hasta hace poco estas garantías no podían movilizarse en los mercados financieros secundarios, lo que desde luego reducía su atractivo para las entidades financieras.

Por ello, se han adoptado en la última década tres reformas legales sucesivas y concurrentes en España, con la finalidad de vitalizar el derecho de superficie como instrumento de las políticas de suelo y vivienda, innovando su régimen sustantivo y financiero.

32 Eso no significa que no haya sido utilizado ni que no empiece a hacerse más intensamente. El Plan de Vivienda de Barcelona 2008-2016 establecía que «la producción de nueva vivienda no destinada a realojamiento llevada a cabo directamente por el Ayuntamiento, mediante el Patronato Municipal de la Vivienda de Barcelona, se hará únicamente en régimen de alquiler y en derecho de superficie». Y el nuevo Plan por el derecho a la vivienda de Barcelona 2016-2025 se propone como reto «aumentar el parque de vivienda de alquiler, pero también otras fórmulas, como la cesión de uso o el derecho de superficie que, en todo caso, garanticen el mantenimiento de la titularidad pública del suelo» (pág. 229, véase también pág. 258). 
El Texto Refundido de la Ley de Suelo y Rehabilitación Urbana, en primer lugar, establece en sus artículos 53 y 54 una nueva regulación del derecho de superficie que introduce novedades de interés en su naturaleza jurídica, su objeto y su duración ${ }^{33}$.

En cuanto a su naturaleza, el nuevo régimen legal abandona definitivamente su tradicional consideración como un mero ius in re aliena, esto es, como un derecho real limitado y limitativo de la propiedad del superficiante, para afirmarlo como una propiedad temporal, separada de la propiedad del suelo ${ }^{34}$. Dicho en otros términos: la Ley abandona definitivamente la doctrina del dominio dividido y abraza la del dominio separado, lo que veremos después que tiene alguna importancia práctica a efectos del mercado hipotecario.

En cuanto a su objeto, hasta ahora nuestra legislación estatal de suelo se refería exclusivamente a la posibilidad de constituir el derecho sobre el suelo para construir una edificación. Ahora se abre también a la posible constitución sobre edificios o sobre elementos privativos de ellos, tales como viviendas o locales de negocio.

Y respecto de la duración, late asimismo en la reforma el mismo espíritu flexibilizador, pues la iguala hasta un máximo de 99 años sea quien sea el sujeto que lo constituya, siendo así que hasta 1975 estaba limitada a un máximo de 50 años cuando lo concedían los entes públicos y desde entonces había sido ampliada a 75 años para los entes públicos y 99 para los privados.

La principal cuestión jurídica que suscita esta regulación legal es la de la función que cumple dentro del sistema de fuentes: la disposición final segunda TRLSRU parece concebirla en su apartado segundo como legislación civil al amparo del artículo 149.1.8. ${ }^{a}$ CE. Elige de esta forma un título competencial «seguro» porque la STC 61/1997, de 20 de marzo, ya ha dejado sentada su cobertura para regular el derecho de superficie en la legislación estatal del suelo. Así las cosas, su aplicación (salvo en lo tocante a los aspectos registrales) cedería ante los regímenes civiles forales o especiales allí donde existen, de conformidad con el apartado 5 del mismo precepto. Sin embargo, el apartado 4 del artículo 40 de la Ley establece que el derecho de superficie se rige por las disposiciones de ese Capítulo, por la legislación civil en lo no previsto por él y por el título constitutivo del derecho.

Esta prevalencia de la propia Ley de Suelo sobre la legislación civil ha sido explicada por la Sala $1 .^{a}$ del Tribunal Supremo en su Sentencia de 26 de noviembre de 2002 haciendo suya la doctrina dualista del derecho. Según el Tribunal Supremo, la regulación de Derecho imperativo del derecho de superficie contenida en la legislación del suelo constituye «una importante excepción al principio espiritualista de libertad de contratación y de autonomía de la voluntad privada», por lo que sólo puede encontrar justificación «en aquellas ocasiones o para aquellos supuestos en que se hallen en juego finalidades de interés público, como sucede cuando la Administración decide utilizar el derecho de superficie como instrumento de intervención en el mercado del suelo, careciendo en cambio del menor fundamento para ser impuestos en las relaciones contractuales de particulares que no tienden a conseguir finalidades sociales, sino auténticamente privadas».

Sin embargo, esta doctrina descansa sobre una concepción del derecho de superficie lejana de la esbozada en los párrafos anteriores (propiedad separada cuyo contenido urbanístico-edificatorio delimita el legislador de suelo atendiendo a su especial función social, quienquiera que lo constituya y cualquiera que sea el interés que persiga) y se aparta claramente de la dicción de la Ley, que contiene también reglas de Derecho dispositivo y se ocupa del derecho «constituido por el propietario del suelo, sea público o privado» (art. 53.2 TRLSRU) pero sólo para la edificación y/o su uso y disfrute (art. 53.1). Si se hubiera querido dictar algunas reglas de Derecho imperativo para asegurar el sometimiento del derecho real de superficie constituido por las Administraciones públicas a los diversos intereses públicos que éstas pueden perseguir, su ubicación lógica habría sido la legislación patrimonial de éstas o la legislación sectorial correspondiente al interés público de que se trate, antes que la Ley de Suelo.

La prevalencia de la legislación de suelo sobre la legislación civil puede más bien ampararse en el artículo 149.1.1. ${ }^{a}$ CE y explicarse así: el legislador del suelo establece las condiciones básicas de la igualdad en el ejercicio de las facultades urbanístico-edificatorias del derecho de propiedad inmobiliaria, como derecho

${ }_{33}$ Sobre el régimen de este derecho en la nueva Ley de Suelo, pueden verse José Ignacio NAVAS, 2007, y M. ${ }^{a}$ Ángeles EGUSQUIZA BALSAMEDA, 2008.

34 El Libro Quinto del Código Civil de Cataluña, relativo a derechos reales (aprobado por la Ley 5/2006, de 10 de mayo), ya había avanzado por el mismo camino. Su artículo 564-1 define al derecho de superficie como «el derecho real limitado sobre una finca ajena que atribuye temporalmente la propiedad separada de las construcciones o de las plantaciones que estén incluidas en la misma. En virtud del derecho de superficie, se mantiene una separación entre la propiedad de lo que se construye o se planta y el terreno o suelo en que se hace». 
de carácter estatutario que está delimitado por la función social que cumple (interés general urbanístico y efectividad del derecho a la vivienda), y eso vale tanto para el pleno dominio sobre los terrenos como también para la propiedad separada del superficiario, en su caso. Confirman esta opinión la ubicación de los artículos 53 y 54 del Texto Refundido dentro de su Título VII, titulado «función social de la propiedad y gestión de suelo» y el hecho de que, a diferencia de su precedente del artículo 287.2 del TRLS de 1992, el artículo 53.1 TRLSRU establezca para los propietarios públicos y privados la misma regulación del destino del bien objeto del derecho que regula.

En consecuencia, en los casos contemplados por la Ley de Suelo (derecho de superficie sobre suelo edificable, o sobre la edificación o sus viviendas u otros elementos privativos), prevalece aquélla sobre la legislación civil, sea general, especial o foral, aplicándose ésta subsidiariamente ${ }^{35}$. En cualesquiera otros casos (por ejemplo, derecho de superficie constituido sobre suelo rural para su siembra, plantación y/o explotación agrícola o ganadera), se aplica plenamente la legislación civil, según su propio orden de prelación de fuentes.

En la primera de ambas hipótesis, todavía hay que resolver otro posible conflicto, y es el que puede darse entre este régimen general y los regímenes especiales que la legislación sectorial establezca para la gestión de determinados tipos de bienes: así, por ejemplo, la legislación urbanística respecto de los patrimonios públicos de suelo ${ }^{36}$ o la legislación de vivienda respecto de las viviendas protegidas ${ }^{37}$. En tales casos, el legislador especial (el autonómico en ambos) superpone al estatuto general del derecho subjetivo un status especial que puede conllevar requisitos, limitaciones, condiciones o controles adicionales para la constitución, ejercicio o enajenación del derecho de superficie, como también para la propiedad o el alquiler, siempre que sean consecuentes y proporcionados con la finalidad de interés público a que obedecen.

La segunda innovación reciente en el régimen del derecho de superficie ha sido la introducida por el Real Decreto 716/2009, de 24 de abril, por el que se desarrollan determinados aspectos de la Ley 2/1981, de 25 de marzo, de Regulación del Mercado Hipotecario. El Reglamento ha incluido por primera vez en su artículo 11 a los derechos de superficie entre los bienes que pueden ser admitidos en garantía hipotecaria de los préstamos y créditos hipotecarios que sirvan de cobertura a las emisiones de bonos hipotecarios, ser objeto de participaciones hipotecarias o servir para el cálculo del límite de emisión de las cédulas hipotecarias. Esto hace más fácil la financiación hipotecaria de la promoción de viviendas sobre inmuebles adquiridos en derecho de superficie, ya que las entidades financieras podrán movilizar esos préstamos y créditos hipotecarios emitiendo con su garantía títulos admisibles en los mercados financieros secundarios.

Como ya se ha advertido, hasta ahora el derecho de superficie estaba excluido de plano del mercado hipotecario, al igual que lo están el derecho de usufructo, las concesiones administrativas o los derechos de pastos, aguas, leñas y semejantes. Las dificultades para admitirlos en el mercado hipotecario eran de dos órdenes: dogmático y práctico.

La primera se refiere a que el artículo 5 de la Ley 2/1981, de 25 de marzo, reguladora del Mercado Hipotecario exige que «los préstamos y créditos a que se refiere esta Ley habrán de estar garantizados, en todo caso, por hipoteca inmobiliaria constituida con rango de primera sobre el pleno dominio de la totalidad de la finca», lo que difícilmente casa con el derecho de superficie concebido como un mero derecho real sobre una propiedad ajena. Esta dificultad se ha visto sorteada, sin embargo, por la configuración legal que de él hace la nueva Ley de Suelo como una propiedad temporal sobre un bien inmueble.

El segundo problema radicaba en que las limitaciones del derecho pudieran excluirlo de su consideración como un "valor suficientemente estable y duradero», requisito asimismo exigido por el mismo precepto legal para los bienes que pueden ser admitidos en garantía para préstamos o créditos hipotecarios. Para superar esta dificultad, ha bastado exigir que su duración supere, al menos, en 20 años al plazo de amortización del préstamo o crédito hipotecarios que sobre ellos se constituya a efectos de permitir su movilización mediante títulos, como ha hecho la modificación del Reglamento del Mercado Hipotecario, teniendo en cuenta además que la Ley de Suelo prolonga hasta un máximo común de 99 años la duración del derecho de superficie, lo que deja un amplio margen para la financiación y su amortización.

35 Así, por ejemplo, el Libro Quinto del Código civil de Cataluña regula el derecho de superficie en sus artículos $564-1$ a 6 y la Ley 1/1973, de 1 de marzo, por la que se aprueba la Compilación del Derecho Civil Foral de Navarra, lo hace en sus leyes 430 a 434.

36 Véase, por ejemplo, los artículos 124.1 de la Ley 2/2006, de 30 de junio, del Suelo y Urbanismo del País Vasco y 236 a 238 de la Ley Foral 35/2002, de 20 de diciembre, de Ordenación del Territorio y Urbanismo de Navarra.

37 Por ejemplo, artículos 82 y siguientes de la Ley 18/2007, de 28 de diciembre, del Derecho a la Vivienda de Cataluña. 
Para que el préstamo o crédito sea elegible como cobertura el Reglamento exige, además de la condición de estabilidad cifrada por relación con su duración ya mencionado, que la edificación o construcción haya sido realizada dentro del plazo previsto para ello en el título constitutivo del derecho (art. 12.6) pues lo contrario extingue el derecho de superficie, de conformidad con lo dispuesto en el artículo 54.5 TRLSRU.

Finalmente, la Ley 11/2009, de 26 de octubre, por la que se regulan las Sociedades Anónimas Cotizadas de Inversión en el Mercado Inmobiliario (SOCIMI) introdujo en España la figura anglosajona de los REIT, ya bastante extendida en los países de nuestro entorno. Con el objeto de captar capitales para la oferta profesionalizada de alquiler, la Ley beneficia con un régimen fiscal supuestamente atractivo a las sociedades que tengan por objeto la adquisición y promoción (incluida la rehabilitación) de bienes inmuebles de naturaleza urbana para su arrendamiento. En lo que aquí interesa, su artículo 2.4 advierte que los inmuebles adquiridos lo deberán ser en propiedad pero acto seguido, y asumiendo plenamente la concepción del dominio separado, establece que «en particular, se entenderá incluida la propiedad resultante de derechos de superficie, vuelo o subedificación, inscritos en el Registro de la Propiedad y durante su vigencia».

$\mathrm{Si}$, a mediados del siglo pasado, el derecho de superficie saltó desde el Derecho civil al Derecho administrativo especial en materia de suelo y urbanismo, medio siglo después parece haber tenido finalmente recepción en el Derecho mercantil y financiero. Se trata sin duda de novedades técnicas y poco vistosas, pero adecuadas para contribuir a erigir políticas y mercados de suelo y vivienda homologables a los de nuestro entorno, al servicio de la efectividad del derecho de los españoles a disfrutar de una vivienda digna y adecuada.

\section{TRES PROBLEMAS ACTUALES}

Los aspectos técnico-jurídicos desarrollados en las páginas precedentes son, sin duda, relevantes para entender las relaciones entre las políticas de suelo y de vivienda y para promover la efectividad del derecho a disfrutar de una vivienda digna y adecuada que es, a la postre, el fin común a ambas por mandato constitucional. Pero no es menos cierto que el debate sobre estos aspectos técnicos nos ha entretenido tradicionalmente, distrayéndonos de otros aspectos no menos relevantes ni tampoco menos problemáticos. Al menos de tres, a cuyo apunte dedicaré las páginas finales de este artículo:

1. La calificación de suelo para vivienda protegida o para vivienda dotacional y la adecuada articulación de la cesión obligatoria y gratuita de suelo, de los patrimonios públicos de suelo o del derecho de superficie, por ejemplo, constituyen obligaciones de medios, no de resultados. Pueden contribuir a políticas de suelo y vivienda más sostenibles y eficaces al servicio de la efectividad del derecho a una vivienda, pero no garantizan su efectividad como derecho subjetivo perfecto. Ya es tiempo de que se dé cumplimiento al mandato constitucional dirigido al legislador para que configure no cualquier Derecho (objetivo) de la vivienda, sino un auténtico derecho (subjetivo) a la vivienda, que quede garantizado (bajo tutela judicial efectiva) a las personas en situación o riesgo de exclusión residencial.

2. El acceso a la vivienda es condición necesaria pero no suficiente para su disfrute efectivo. Para éste hace falta además el mantenimiento pacífico en dicho disfrute. En tiempos de auge inmobiliario, dicho mantenimiento en el disfrute efectivo se vio cuestionado en las grandes áreas metropolitanas por el fenómeno del acoso o mobbing inmobiliario. Y en tiempos de crisis financiera e inmobiliaria, se ha visto asimismo inquietado por el fenómeno de los desahucios de personas y familias socialmente vulnerables e inmersas en situaciones de necesidad. Estos problemas demandan un nuevo Derecho administrativo de la vivienda, dotado de medidas preventivas y también correctivas de los abusos de derechos o de su ejercicio antisocial.

3. La eficacia de las políticas de vivienda pasa por destinarles recursos suficientes de forma sostenida. Tales recursos son, principalmente, suelo y financiación. En España, en las últimas décadas hemos calificado mucho suelo para vivienda protegida. Pero ni siquiera éste era provisto de forma eficaz a subvenir las necesidades de forma estable: suelo que era vendido sin controlar su destino final, suelo destinado a una vivienda protegida que no llegaba a construirse o que era descalificada al cabo de unos años, etc. Así que no ha sido capaz de compensar la manifiesta escasez de financiación dedicada a las políticas de vivienda en España, si la comparamos con nuestros países vecinos. El siguiente cuadro sobre el gasto público social en España comparado con la media de los países de la Unión Económica y Monetaria de la UE (UEM) expresa bien a las claras esta escasez: 
REALA. Nueva Época - N. 7, mayo 2017 - ISSN: 1989-8975 - DOI: 10.24965/reala.v0i7.10421 - [Págs. 68-85]

Planes urbanísticos y planes de vivienda: la extraña pareja

Marcos Vaquer Caballería

\begin{tabular}{lcll}
\hline UEM = 100 \% & $\mathbf{1 9 8 0}$ & $\mathbf{2 0 0 7}$ & $\mathbf{2 0 1 3}$ \\
\hline PIB & $\mathbf{7 4 , 4} \%$ & $96,2 \%$ & $84,8 \%$ \\
\hline Educación & - & $84,1 \%$ & $69,9 \%$ \\
\hline Sanidad & $56,0 \%$ & $82,5 \%$ & $69,0 \%$ \\
\hline Seguridad Social & $56,5 \%$ & $74,9 \%$ & $82,8 \%$ \\
\hline Vivienda & $19,6 \%$ & $45,0 \%$ & $31,0 \%$ \\
\hline
\end{tabular}

Fuente: Banco de España, Síntesis de indicadores.

Así que en 2007, justo antes del estallido de la crisis y cuando nuestro PIB ya estaba casi equiparado al valor medio de la UEM, el gasto público destinado a políticas de vivienda ${ }^{38}$ todavía representaba menos de la mitad de la media (el $45 \%$ ), un dato ya pobre pero que además se ha deteriorado notablemente desde entonces por efecto de la crisis, de forma que en 2013 (último año disponible al tiempo de redactar este trabajo) ya ni siquiera gastamos en vivienda un tercio (el $31 \%$ ) de lo que lo hacen los de media los Estados de la UEM.

Este es otro síntoma más del «casticismo» (Vaquer, Ponce y Arnaiz, 2016: 13) de las políticas de vivienda en España y si no nos afanamos por superarlo, difícilmente podremos homologar sus objetivos y resultados a los de los países de nuestro entorno. Pues como dice el refrán, no es posible hacer una tortilla sin romper un huevo.

\section{BIBLIOGRAFÍA DE REFERENCIA}

ALLI ARANGUREN, Juan Cruz, 2005: "Urbanismo y vivienda. La interrelación de las políticas de suelo y vivienda (Conferencia en el III Congreso Español de Derecho Urbanístico. Pamplona, 25 de mayo de 2005)", Revista de Derecho Urbanístico y Medio Ambiente, núm. 219, julio-agosto.

BAÑO LEÓN, José María, 2005: "Patrimonios públicos del suelo y vivienda", Cuadernos de Derecho Local, núm. 7.

- 2001: "La actividad urbanística en la financiación de las haciendas locales", Revista Valenciana de Economía y Hacienda, núm. 2.

EGUSQUIZA BALSAMEDA, M. a Ángeles, 2008: "La aplicación del derecho de superficie de los artículos 40 y 41 del Real Decreto Legislativo 2/2008, de 20 de junio: situación en Navarra", Revista Jurídica de Navarra, núm. 45.

HERCE, José A., LÓPEZ GARCÍA, M. A., Rodríguez, Julio, y Taltavull, Paloma, 2005: "El papel del suelo en el mercado de viviendas", Economistas, núm. 103.

IGLESIAS GONZÁLEZ, Felipe, 2005: “La intervención pública en el mercado de vivienda como política social”, en Documentación Administrativa, núm. 271-272: El Derecho público de la acción social.

LEAL MALDONADO, Jesús, 2002: "Segregación social y mercados de vivienda en las grandes ciudades", Revista Española de Sociología, núm. 2.

LÓPEZ RAMÓN, Fernando (coord.), 2010: Construyendo el derecho a la vivienda, Madrid, Marcial Pons.

MENÉNDEZ REXACH, Ángel, 2016: Ordenación del territorio supramunicipal y urbanismo municipal: una distinción imposible a la vista de las actuaciones de interés regional, en GIFREU, BASSOLS y MENÉNDEZ REXACH, dirs., El derecho de la ciudad y el territorio. Estudios en homenaje a Manuel Ballbé Prunés, Madrid, INAP.

NAVAS ORTIZ, José Ignacio, 2007: "El derecho de superficie en la nueva Ley de Suelo", Ciudad y Territorio. Estudios Territoriales, núms. 152-153.

PAREJO, Luciano, y FERNÁNDEZ, Gerardo Roger, 2009: Comentarios al Texto Refundido de la Ley de Suelo, Madrid, lustel.

PONCE SOLÉ, Juli, 2001: "Derecho urbanístico y segregación espacial”, Ciudad y Territorio. Estudios Territoriales, núm. 130.

- 2004: Solidaridad, cohesión social y derecho público: a propósito de las reservas legales de vivienda social como instrumento de desarrollo urbanístico sostenible, en VV.AA., Diversidad y convivencia en las ciudades: ponencias presentadas al II Seminario "Pensando lo local en un nuevo siglo", Barcelona, Fundació Carles Pi i Sunyer d'Estudis Autonòmics i Locals.

38 Este déficit, bastante más agudo que en las demás políticas sociales, puede explicarse en parte por la detracción de muchos recursos públicos por la deducción por adquisición de vivienda en el IRPF. Ahora bien, esto puede ser una explicación pero no una justificación, habida cuenta del carácter regresivo y escasamente eficaz de esta medida fiscal para los fines de la política de vivienda. 
PORTO REY, Enrique, 2001: “Técnicas urbanísticas que pueden facilitar la promoción de viviendas de protección pública", Revista de Derecho Urbanístico y Medio Ambiente, núm. 185.

SÁNCHEZ DE MADARIAGA, Inés, 1998: La práctica urbanística emergente en los Estados Unidos. Un análisis desde la perspectiva europea, Madrid, Universidad Carlos III de Madrid/BOE.

TEJEDOR BIELSA, Julio, 1998: Un modelo urbanístico alternativo: el Derecho francés, Barcelona, CEDECS.

VAQUER CABALLERÍA, Marcos, 2016: La ordenación del territorio y su relación con el urbanismo: configuraciones y desfiguraciones legales desde 1956 hasta hoy, en GIFREU, BASSOLS y MENÉNDEZ REXACH, dirs., El derecho de la ciudad y el territorio. Estudios en homenaje a Manuel Ballbé Prunés, Madrid, INAP.

- 2014: Las transformaciones de la política de fomento en materia de vivienda en España: el nuevo Plan Nacional de Vivienda, en VV.AA., I Congreso Nacional sobre Vivienda Social. Sevilla, 14 y 15 de marzo de 2014. Libro de actas, Sevilla, Real Fundación Patronato de la Vivienda de Sevilla.

- 2011: La eficacia y la efectividad del derecho a la vivienda en España, Madrid, lustel.

VAQUER CABALLERÍA, Marcos, PONCE SOLÉ, Juli, y ARNAIZ RAMOS, Rafael, 2016: Propuestas jurídicas para facilitar el acceso a la vivienda, Madrid, Fundación Coloquio Jurídico Europeo.

VILLAR EZCURRA, José Luis, 1980: "Nuevas orientaciones en el régimen de protección pública a la vivienda", Revista de Administración Pública, núm. 91.

VINUESA, Julio, DE LA RIVA, José María, y PALACIOS, Antonio J., 2009: "Política de vivienda y urbanismo", en VV.AA. Vivienda social ahora, monográfico de Ciudad y territorio. Estudios territoriales, núms. 161-162. 